\title{
A!
}

This is an electronic reprint of the original article.

This reprint may differ from the original in pagination and typographic detail.

Lehtonen, Miikka J.; CHEW, JiaYing

\section{Developing design literacy for social agency}

\section{Published in:}

Developing design literacy for social agency

DOI:

10.33114/adim.2019.02.223

Published: 01/11/2019

Document Version

Publisher's PDF, also known as Version of record

Published under the following license:

CC BY-NC-SA

Please cite the original version:

Lehtonen, M. J., \& CHEW, J. (2019). Developing design literacy for social agency. In Developing design literacy for social agency (1 ed., Vol. 2, pp. 1307-1317). (Conference proceedings of the Academy for Design Innovation Management). Academy for Design Innovation Management. https://doi.org/10.33114/adim.2019.02.223

This material is protected by copyright and other intellectual property rights, and duplication or sale of all or part of any of the repository collections is not permitted, except that material may be duplicated by you for your research use or educational purposes in electronic or print form. You must obtain permission for any other use. Electronic or print copies may not be offered, whether for sale or otherwise to anyone who is not an authorised user. 


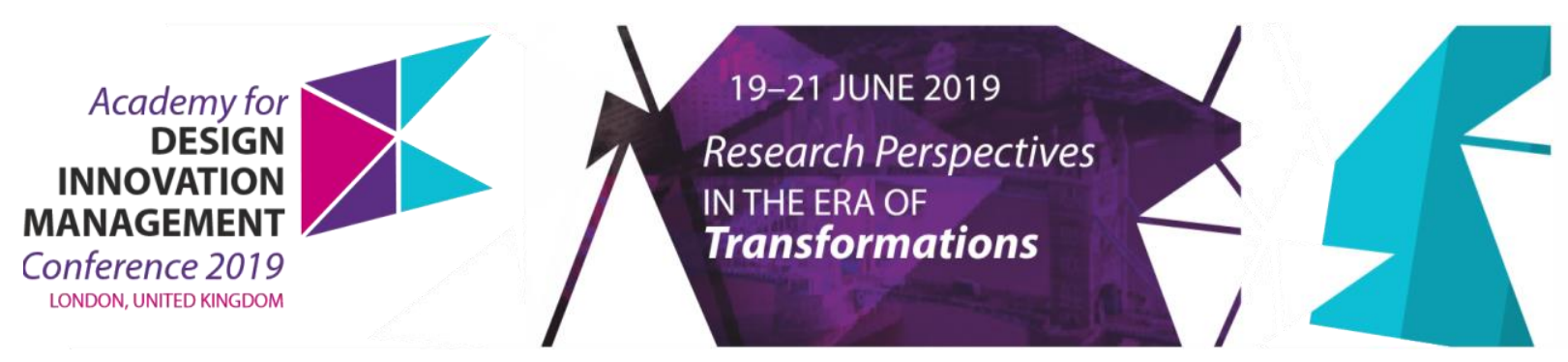

\title{
Developing design literacy for social agency
}

\author{
LEHTONEN Miikka J. $^{\mathrm{a} *}$ and CHEW JiaYing ${ }^{\mathrm{b}}$ \\ a Dubai Institute of Design and Innovation, UAE \\ ${ }^{b}$ Aalto University School of Business, Finland \\ * corresponding author e-mail: miikka.lehtonen@didi.ae \\ doi: 10.33114/adim.2019.02.223
}

\begin{abstract}
Preparing a workforce that is well-equipped with the skills and knowledge to navigate the complexities of our global human society is a key responsibility of design and higher education. Extant research has advocated design as one of the essential skills to master in the future, and this design literacy has been claimed to be a critical factor in creating innovations and new solutions towards transforming our societies. To explore how nondesigners become more design literate, in this paper we present findings from a study looking at how multidisciplinary student teams develop their design literacy in an actionoriented course setting. Based on our initial analysis, blending the boundaries between universities and the surrounding society positively contributes towards developing design literacy. This, in turn, has pedagogical implications as well as increases our understanding on how design travels to other disciplinary domains.
\end{abstract}

Keywords: design education, empathy, societal impact, curriculum design, transdisciplinarity

\section{Introduction}

The real world is not like the university. In the university, professors make up artificial problems. In the real world, the problems do not come in nice, neat packages. They have to be discovered. It is all too easy to see only the surface problems and never dig deeper to address the real issues. (Norman, 2013, p. 218)

In the quote above, Norman (2013) gently touches upon the concept of wicked problem (Buchanan, 1992; Coyne, 2005; Rittel \& Webber, 1973) that has been established as one of the seminal concepts in design practice. Especially now, with discourses around sustainability and intergenerational justice gaining traction, higher education institutions teaching design or its extensions (such as design thinking) ought to broaden their repertoire from teaching design as a craft to design as means of creating agency to solving wicked problems (Burdick \& Willis, 2011; Christensen et al., 2016). While we acknowledge that such initiatives have been gaining traction globally in several higher education institutions during the turn of the century, at the same time it is also justified to constructively question what are the underlying political, societal, and economic paradigms that govern and frame how and why we teach design to our students. In a similar vein, extant research has questioned the value and validity of skills students acquire in higher education institutions (Arum \& Roksa, 2011; Fink, 2013), and findings from these studies are alarming in the sense that if higher education institutions are not capable of educating their students with transferrable skills, where will they acquire these skills?

The study at hand, however, does not take a cynical stance to higher education nor do we expect to create a causal relationship between transforming higher education and solving wicked problems. In line with extant literature on design and design literacy more specifically (Burdick \& Willis, 2011; Christensen et al., 2016;

This work is licensed under a Creative Commons Attribution-NonCommercialShare Alike 4.0 International License. https://creativecommons.org/licenses/by-nc-sa/4.0/ 
Nielsen \& Braenne, 2007), our aim in this paper is to contribute to research on design literacy by investigating how students in a multidisciplinary graduate program (consisting mostly of design, engineering, and business students) develop and reflect on their design literacy for social agency. More specifically, research question formulated for this study is as follows:

How does multidisciplinary and action-oriented course design contribute to students' design literacy towards social agency?

Instead of seeing design thinking (e.g. Cross, 1980; Dorst, 2011; Kimbell 2011, 2012; Rowe, 1987) as a set of tools and methods but rather as a manifestation of design literacy enables us to reflect on what we could be teaching when we teach design thinking. What is more, we argue that course designs that weave together theoretical reflections and real world challenges have the potential to instil our students with a sense of agency: that is to say, developing design literacy is not only about mastering design tools and practices, but understanding how they can be utilized for creating positive impact in the surrounding world. As Coyne (2005, p. 6) highlights, testing solutions to wicked problems are seldom undone, which is why design education plays a crucial role in helping students negotiate the relationship between the problem and the solution space and their stance towards it. As a concrete output, in this paper we present the SCET (Space - Community Emotions - Transformation) framework as means to developing design literacy towards social agency.

As mentioned above, course settings with assignments that blend the boundary between the university and the surrounding society are especially fruitful for exposing our students to wicked problems as well as to help them discover them on their own. Moreover, taking design education as the point of departure and bringing students from other fields in touch with design further illustrates how design and design education can serve as catalysts for societal change (Cross 1980, 1984; Glasser, 2018).

In this enquiry, we draw on a multitude of data: students' reflections via their visual learning diaries, interviews with our partners, and finally autoethnographic observations and reflections. While the visual learning diaries enable us to explore how design literacy is manifested and developed amongst the participants and partner interviews provide us with insights on how such course designs are perceived to create value amongst our stakeholders, autoethnography makes our role as instructors and researchers explicit in the data collection period. That is to say, we are not just observing the field but simultaneously shaping and making sense of it (Anderson, 2006).

The rest of the paper is structured as follows: first, we discuss extant literature on design literacy and higher education, then we introduce the proposed framework for curriculum redesign and application to a course context. After, we briefly describe our research methodology and initial findings in this ongoing research before concluding with our next course of action.

\section{Literature review: design literacy and higher education}

\section{Design literacy as spatio-temporal transcendence}

When talking about design literacy, spatio-temporal transcendence is perhaps one of the most critical conceptual approaches towards understanding design and its value. In essence, design can be understood as conscious acts of improving the status quo (Simon, 1969, p. 55) or similarly as a practice aimed towards the future, and as such it is to a large extent about "acting in and on the world" (Yelavich, 2014, p. 12). As Yelavich (2014, p. 12) continues, "how and where design can contribute to conversations larger than itself" highlights the desire among practitioners and researchers of design to move away from design as a competitive advantage towards design as socio-political mindset towards future and contemporary societies. That is to say, spatiality in design refers to the designer engaging with the problem space here-now by attempting to empathically transcend their own boundaries, whereas temporality refers to crafting the solution space for the future society (Müller, 2018), and here empathy is also one of the key elements. Similarly, movements between the problem space (here-now) and the solution space (future society) can be seen as manifesting validations of design literacy. Thus, for the designer to be able to transcend their spatio-temporal boundaries and in the process develop their design literacy requires empathy.

Given that empathy is such a crucial element in design and various other disciplines, extant research in design (Ho, Ma \& Lee, 2011; Hess \& Fila, 2016; Smeenk, Sturm \& Eggen 2018) and higher education (Ashworth \& Lucas, 2000; McAllister \& Irvine, 2002; Killick, 2012) has explored empathy from diverse perspectives. Especially in design, considerable amount of scholarly attention has been devoted to understanding our users 
and stakeholders to frame the problems we aim to solve (Brown, 2008; Dorst, 2011). It points to leaving preassumptions at the door; stepping into someone's shoes and trying to explore how they interact with and experience the world. One of the earliest lessons taught in design education, is the difference between Sympathy and Empathy (Brown, 2013).

However, instead of seeing them as disconnected ideological constructs, we believe that the element of "care" appears to fill the transition void between reactions of "sympathy" and learning the ways of "empathy". Especially because one may feel sympathy towards issues observed in their lives, but taught to employ empathy in assigned situations that lack resonance. Indeed, if higher education institutions teach empathy as a sort of driver for innovation and design-driven outputs, can we speak of empathy as a genuine desire to understand the needs of others?

Customarily, we teach methods and tools to generate user insights that would fuel creative and meaningful solutions. We engage external partners to provide students with first hand experiences, and allow them to work on real issues in the industry and society. Many of these concepts are then evaluated on their novelty, and potential value to generate revenue. The projects are largely driven by commercial value, as is a matter of fact that most project briefs are highly dependent on paying clients and their organisation's demands.

In an ecosystem that relies on these engagements, it would be unrealistic and naive to imagine that the universities would function any differently. Yet, there are numerous social challenges in the world that would benefit from the knowledge and skills we teach, and if we do not nudge our students to start thinking about them, who will?

\section{Higher education institutions as catalysts for social change}

Universities were conceived to develop a compliant workforce with skills of print literacy and discipline that would enable them to function in modern corporations and a corporate economy (Dewey, 1938; Kellner, 2003). As a result, higher education institutions are viewed as the most legitimised social agent of creating, discovering, disputing, accepting and disseminating epistemology and its agreement process (Clark, 1998; Marginson \& Rhoades, 2002; Hyun, 2011).

In an age of rapid globalisation brought about by exponential development in technology, communication and transportation, it has become increasingly difficult to anticipate the changes impacting society and lifestyles, that much time is spent focusing on utilising technology and creativity for innovations and businesses. Yet, at the same time, as these changes "become concrete only in the consequences which result from their application" (Dewey, 1938, p. 19), we ought to be more mindful of pedagogical decisions. Consequently, neglecting the fundamental social and environmental issues that deserve our attention as well (Stegall, 2006; Thorpe \& Gamman, 2011).

Social challenges prevalent before are even harder to ignore now, especially because of digitalisation and our interconnectedness. Viral reports in the mass media make us wish that we could do our part in supporting those who are less privileged or effect change in unfavourable circumstances, yet why are we not doing anything? Do we lack the capacity and/ or orientation?

Spearheading these endeavours, governments around the world have involved academics and private companies in an array of research and consortium projects (e.g. Ambos et al., 2008; Ankrah \& AL-Tabbaa, 2015; Bruneel et al., 2010). However, does everything have to be top-down? Is it only possible to tackle these challenges when there is provision from those in power? There seems to be a structure-agency dichotomy that we are not addressing.

An answer to this need and a trailblazer of its time, International Design Business Management, Aalto University's transdisciplinary graduate program, was established in the mid-nineties with the concept to educate future design managers capable of generating revenue and competitive advantages through design predominantly in large corporations. However, with the ever-changing needs of societies, graduates of the program could potentially be in positions where they lead and manage policy change, grow enterprises or champion social movements.

\section{Framework for curriculum (re)design}

In recent years, calls for transforming higher education institutions have been raised globally, and as this can be approached as a collaborative effort, most of our teaching methods and contents can be accessed online. In 
line with this, here we elaborate on our pedagogical framework that illustrates the main building blocks onto which we base our initiatives. The SCET framework is our first attempt at analytically articulating how to bridge the gap between sympathy and empathy, and as such it is to be taken as framework-in-the-making.

- Learning is not restricted to a physical space we call 'university campus' (Proserpio \& Gioia, 2007; Redpath, 2012)

- Learning is about leaving the ego behind: it is not a competition, but a collaborative effort to improve ourselves as well as our society (Bain, 2004)

- Learning is an emotional experience: getting your hands dirty, goosebumps, breaking away from existing patterns (Herrington, Reeves \& Oliver, 2010; Meyer \& Turner, 2006)

- Learning is transformative, and as such it transforms not only you but also others around you (Mezirow, 1991; Taylor, 1997)

More specifically, the table below fleshes out some of the roles and responsibilities for both teachers and students in the SCET framework introduced above.

Table 1: Roles and responsibilities in the SCET framework

\begin{tabular}{ccl}
\hline Dimension & Teacher's roles and responsibilities & \multicolumn{1}{c}{ Student's roles and responsibilities } \\
\hline Designing and identifying the & $\begin{array}{l}\text { Participating in nurturing a good } \\
\text { atmosphere in the space, }\end{array}$ \\
learning spaces in and outside the & campus & $\begin{array}{l}\text { reflecting on the meaning of } \\
\text { space when it comes to each } \\
\text { individual's learning }\end{array}$
\end{tabular}

\begin{tabular}{lcc}
\hline Community & $\begin{array}{c}\text { Appreciating the knowledge and } \\
\text { experiences students have, and } \\
\text { attempting to active this in the } \\
\text { learning process }\end{array}$ & $\begin{array}{c}\text { Actively communicating about } \\
\text { their knowledge and experiences } \\
\text { to others, ensuring others are } \\
\text { being heard }\end{array}$ \\
\hline Emotions & $\begin{array}{c}\text { Willingness to revise and develop } \\
\text { the course after each iteration, } \\
\text { reflecting on their own interests } \\
\text { and competencies as a basis for } \\
\text { new pedagogical content }\end{array}$ & $\begin{array}{l}\text { Openness towards new ways of } \\
\text { learning, respecting their peers, } \\
\text { understanding that courses can } \\
\text { be open-ended with the teacher } \\
\text { merely designing the structure }\end{array}$ \\
\hline $\begin{array}{c}\text { Appreciating change and } \\
\text { embracing ambiguity, clearly } \\
\text { communicating this in connection } \\
\text { with the learning objectives to } \\
\text { the students }\end{array}$ & $\begin{array}{c}\text { Exploring their intrinsic and } \\
\text { and learning, trusting the teacher } \\
\text { in that ambiguity and open- }\end{array}$ \\
\hline
\end{tabular}

The thoughts above have been formulated based on our teaching experiences in several countries (most notably Finland, Denmark, India, Japan, Singapore and Russia), extant research, and engaging in discussions with our colleagues from different higher educational institutions over the world. Furthermore, we cannot and perhaps should not - control what the students learn (this would imply control over their previous experiences), but we can draw on various methods and processes to enable the students to take ownership of their learning and thus formulate their own stance to the sympathy - empathy continuum (Dewey, 1930; hooks, 1994).

\section{The SCET framework in practice: Care through iteration}

An opportunity surfaced for us to test this framework during the transition of program leadership in 2017. This put us in a favourable position to act as a wind tunnel for this transformation in higher education, and marked the inauguration of our course, IDBM Challenge: A mandatory 3-week introductory course that brings together students from diverse cultural and educational backgrounds, and provides a setting for combining theory with practice. Through practical experience, learning-by-doing, critical and meaningful reflection; students acquire the skills to research, conceptualize, develop and introduce socially sound and commercially successful 
solutions. In this context, learning-by-doing does not refer to doing that is complemented by superficial learning afterwards, but instead it echoes with Dewey's (1930, p. 390) knowledge and knowing duality as well as with hooks's (1994) attention to question the mind-body separation in the classroom through the concept of eros. Thus, learning-by-doing is essentially about being present in the world, interacting with it, and creating knowledge through our body and mind.

The first author has taught IDBM Challenge since 2016, and although the first iteration of the course was named differently, the learning outcomes and 3-week structure have remained the same. Being the introductory course, the reasons behind the structure focus on interpersonal relations: namely, by starting the program with an intensive course creates a space where everyone can get acquainted with their peers and thus create a sense of transdisciplinary community already from the get-go.

Moreover, being a challenge-based course where the theme changes every time the course is taught ensures students' focus on the learning experience rather than consulting their peers who already took the course, on how to optimize their participation. Thus, the course should be understood as a living organism that enables its participants to take ownership of their learning experience.

\section{First iteration in 2017: speculative design and outer space}

The 2017 iteration was when we first started to consciously pay attention to the pedagogical philosophy and specifically, course design. Challenge for this course focused on combining speculative design (Dunne and Raby, 2013) and outer space by allocating the teams to four decades (2027-2057) with each having its unique brief and setting. For example, in one of the settings the students extrapolated how the current behaviors and challenges could potentially affect how we live, forcing us to eventually move on to live on Mars.

In addition to the team-specific challenge, as a cohort the participants were also expected to organize a multisensory event showcasing their challenges and solutions. This design, then, emphasized learning to take place in three interconnected dimensions: individual, team and cohort to highlight the networked nature of learning (Schenck and Cruickshank 2015). Building on this, while the structure design for the course seemed to create spaces for the students to reflect on and act upon design as a catalyst for social and societal change, the fact that the provided challenges were quite abstract provided us with a sounding board for the 2018 edition that shifted the focus from outer space and future to our immediate surroundings and near future.

\section{Second iteration in 2018: social innovation in first world cities}

Using the course as a primer for students to start thinking creatively (and reflectively) about society's "wicked problems" (Rittel \& Webber, 1973), we identified a recurring global theme that serves as a point of convergence across the public, private and third sector: the United Nations' Sustainable Development Goals (UNSDGs). However, we noticed that the subject often features developing countries and the predicament of those who may be trapped in unfortunate situations. In contrast, we often refer to countries such as Finland, Singapore, and Denmark as prime examples for other nations (Teo, 2018), and thus in the process forgetting that these developed countries, too, have their flaws that demand attention.

Therefore, we created a twist on the familiar topic for the 2018 iteration of the course by providing the multidisciplinary teams with the following design brief:

Five UNSDGs applied to the context of first world cities that the students currently reside in.

"What does poverty look like in a first world country?"

Two to three teams were assigned to each SDG and tasked to develop concepts that would create positive impact within five years.

In this edition, other than the intentional set-up around the challenge brief, we also structured the course to facilitate the projects that each team was working on. Although we did not explicitly refer to any framework or design process in our teaching content, we enforced key milestones (mandatory sessions) to gently guide the students in adopting the design process by taking them through the various phases of a design project: Research, Insights, Ideation and Validation.

i. $\quad$ Research (Desk and Field)

As these topics were relatively new to the students, we spent a considerable amount of effort in nudging them to think outside of their comfort zones, and to explore the boundaries by physically 
going to the field to look for answers. Rather than simply looking at statistics of these pertinent issues, students did field research by conducting interviews with stakeholders. To increase relevance and realism of the challenge, we kick-started the projects with organisation visits in collaboration with partners around the city. This enabled the students to have first-hand experience in witnessing that these challenges are not just conjectures, but discounted (and disregarded) issues. All teams partook in these organised visits, and some even made cold calls to other Non-Governmental Organisations to get a better grasp of the context and challenges around their given briefs. This allowed them to quickly get a good sense of the situation's challenges and user needs.

ii. Insights Analysis

Through the intensive field research in the first week, participants then sat down in teams to crystallise and distil their findings into actionable insights. These were done over a series of mentoring sessions. Students did ideation concurrently due to the short time frame given.

\section{iii. Ideation}

In the ideation phase, students were encouraged to use the Sanpo-Yoshi framework as a guideline for developing the concepts. The framework emphasizes the importance of systemic value: us - client society. This not only gave the students a sense of agency, but also allowed them to consider factors beyond the monetary or novelty factors of a typical innovation project.

\section{iv. Validation}

As this was an intensive 3-week course, students did not have the luxury of time to prepare prototypes. Nevertheless, they discussed their ideas with relevant stakeholders throughout the process and finally presented their solutions to a 60-pax audience at a multisensory event they organized at the end of the course. At the event, each team presented their concepts in a PechaKucha format (20 slides $x 20$ seconds), where teams used a variety of creative storytelling methods to best pitch their concepts. Some presented imagined future scenarios through digitally edited images, while others suggested potential services through a website mock-up or physical artefacts. Each were compelling in their own ways and told of stories that not only demonstrated the students' dedication and interests to the topic or project, but also evoked a sense of agency that shows that they were motivated to effect change in their own ways.

As the historical account of IDBM Challenge above illustrates, the way this course has been designed has evolved throughout the years to further develop the students' design literacy and competences. By adopting a designer's mindset to developing the course, we have explored both the brief and the methods to see what kind of constellations would enable us to create a learning space conducive to nurturing design literacy. By the same token, by blending the boundary between the university and the surrounding society we also enable the course iterations to be influenced by actors outside the university setting. Thus, what we are teaching to our students is also put into practice when designing the course.

\section{Research methodology: Exploring the emergence of design literacy}

As the final assessment of the course, students were tasked to submit a Visual Learning Diary in which they were expected to demonstrate what they have learnt by reflecting on the happenings and insights of the course; documenting their thoughts and takeaways from the (lectures and workshops) sessions, taught content (readings, online episodes) as well as team work and community involvement for event planning. Content and stylistic conventions were not evaluated: as long as the participants covered the required topics, they would get maximum points for the assignment. This design decision, then, helped the participants focus on their learning experience instead of hunting for the maximum points.

The visual learning diaries act as basis for analysis on two dimensions: not only do they provide substantial data to assess our pedagogical methods and how the students articulate their design literacy, but they also offer an exceptionally intimate view on how the individuals have experienced the course. Students' course feedback online and during the final reflection session also serve as good measure. During the first session of the course, we sought permission from the students to use their outputs as research data, and since no one declined our data set consists of sixty-seven visual learning diaries. While we will be showcasing excerpts from 
the diaries throughout the remainder of this paper, parts of the diaries that might identify the student will be covered or blurred out to respect the students' anonymity.

In addition, interviews with our partner organisations (both public and private) have allowed us to better understand whether there was industry relevance in the solutions developed by our students, and if this format of a course is suitable for continuity. As of writing this paper, the second author has conducted two interviews with our partners: these interviews lasted approximately sixty minutes and they were recorded, and immediately afterwards transcribed also by the second author.

Finally, as being active designers and participants in the process, we used autoethnography to reflect on how our course design decisions have enabled or disabled care and conceptualizations for the emergence of care (Anderson, 2006). Since care as a phenomenon and a way of being in the world is fragile (hooks, 1994), triangulating research data enables us to carefully analyse how course design can support care and how the participants craft their stance to it. The table below summarizes the dataset utilized in this study:

Table 2: Data collected for this study

\begin{tabular}{|c|c|c|}
\hline Type of data & Key statistics & Purpose in this study \\
\hline $\begin{array}{l}\text { Visual learning diaries in digital } \\
\text { format }\end{array}$ & Sixty-seven learning diaries & $\begin{array}{l}\text { Analyzing the learning journey as } \\
\text { well as how design literacy } \\
\text { emerges and is articulated by the } \\
\text { participants }\end{array}$ \\
\hline Partner interviews & Two transcribed interviews & $\begin{array}{l}\text { Supportive material for } \\
\text { understanding how the course } \\
\text { enables blending the boundary } \\
\text { between academia and the } \\
\text { surrounding society }\end{array}$ \\
\hline Autoethnographic observations & $\begin{array}{c}\text { Notes from debriefings after } \\
\text { course contact sessions, internal } \\
\text { communication and artefacts } \\
\text { focusing on course design and } \\
\text { implementation, video recordings } \\
\text { of the sessions }\end{array}$ & $\begin{array}{l}\text { Analyze the design decisions and } \\
\text { consequences of the facilitators }\end{array}$ \\
\hline
\end{tabular}

At this point it should be noted that the visual learning diaries are our main source of data with the interviews and our observations providing additional flesh around the analysis. We analyzed the diaries as multimodal texts (Kress and van Leeuwen, 2006; Rose, 2016) documenting students' learning experiences throughout the course; as such, main emphasis is not on validating whether the students actually learned what they reported in the diaries, but instead to look at the journey they went through during the course. What is more, as extant research on design literacy has focused on empirically exploring how students understand inquiry in connection to design (Christensen et al., 2016), our study extends this body of knowledge by looking at how inquiry - and hence design literacy - emerges over time. To illustrate this, Figure 1 is an excerpt from one of our participant's learning diary. 


\title{
Week 2. D7
}

The cold call to Shortcut made us see how ignorant we have been on the whole refugee situation- how delicate we have to approach the issue. Intense ideation workshop session with the team. Looking back, the main issue is that as a team, we did not realize how different we operate as everyone has different ways of problem-solving. Given the tight schedule of ideating and coming up with solutions, quickly learning to understand what each other means seems the key. Languange is never perfect. Have an open mind and always try to empathize those you're talking to.

\begin{abstract}
Task Note: past experience validating an idea. I once pitched a new collection design to a focus group of clients in healthcare which was received very well. It also gave me an insight that a certain color should be avoided in medical setting. The takeaway was that combining other's perspectives and validate my own can yield much more fruitful outcome than a single idea that can be very limited
\end{abstract}

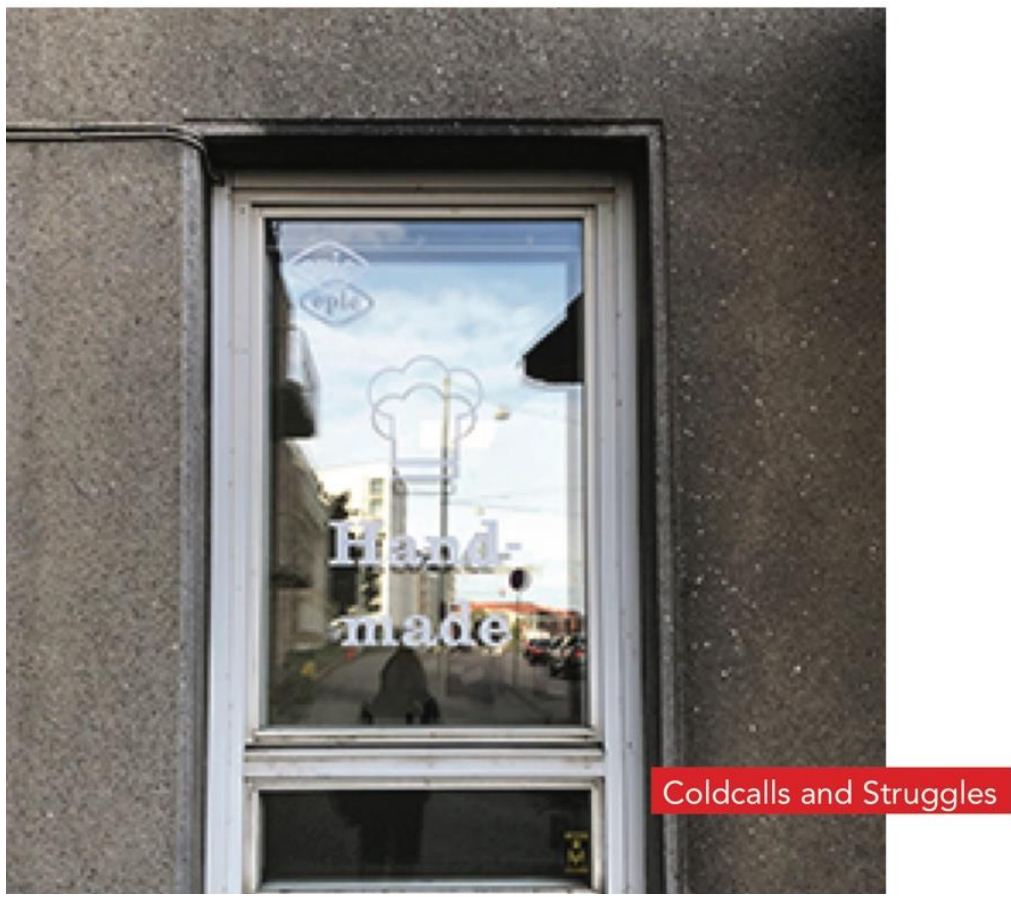

Figure 1. An excerpt from Participant \#5's visual learning diary.

As the participant writes, "[t]he cold call to Shortcut made us see how ignorant we have been on the whole refugee situation - how delicate we have to approach the issue" and "[l]ooking back, the main issue is that as a team, we did not realize how different we operate as everyone has different ways of problem-solving" - both of these descriptions show how interacting with the surrounding society triggers relevant reflections on developing design literacy.

Acknowledging the multisensory nature of design - and nudging our non-design students towards multisensory expression - we framed the learning diary as visual, and as such they were analyzed as multimodal texts (Kress and van Leeuwen, 2006; Rose, 2016) by utilizing the Gioia methodology (e.g. Gioia \& Chittipeddi, 1991; Gioia, Corley, \& Hamilton, 2012). In short, the Gioia methodology aims at creating transparency and rigor in qualitative research by generating theoretical insights through the respondents' lived experiences. That is to say, first-order concepts in Gioia methodology are directly derived from the data, whereas the second-order themes are crafted by the researcher, and finally the third level constructs are more theory-driven. As of writing this paper, our data analysis is still in the process, and below we will shed light on our initial findings. 


\section{Initial findings on developing design literacy}

Our initial findings suggest that design literacy for social agency in classroom settings is positively influenced by the following three concepts: interaction with the surrounding environment (Space), multidisciplinarity (Community), and porous learning content (Emotions). Below, we will go through these separately before bringing them together.

First, through deliberate design, we have forged a foundation that supports an individual's learning on several levels - personal, team, community - and dimensions. We have found that this set-up enables reflexion and reflection (Schön, 1983), which contributes considerably to the forecasted denouement of a sense of belonging and establishment of trust amongst peers early on. Furthermore, as one of our guiding principles in designing the course focused on 'taking the university where the students are', we are also interested in seeing how different activities and learning spaces contributed to developing (or hindering) design literacy. In this context, then, porous learning content refers to curating a selection of videos, podcasts, and articles that enable the participants to approach design from diverse perspectives such as technology, teamwork, and management. Based on the participant feedback from the course's 2017 iteration, video episodes were significantly condensed (from sixty to fifteen minutes on average) and more explicitly connected to the design brief, and this seemed to create positive impact towards developing design literacy as criticism towards the episodes this year was significantly reduced. That is to say, the less technology clutters the learning process, the more time and cognitive capacity the participants have to develop their design literacy.

We identified through the compositions, that this intensive course is often an emotional experience for our students as they discover the extents of their capabilities, while forming alliances to tackle tasks beyond their means. This is an important factor in constructing individual perspectives, a determinant between "feeling for" and "feeling with"; made possible as the students display a controlled level of vulnerability that permits them to be more receptive, and in turn, empathic. From design literacy's point of view, this implied a departure from seeing design as a set of tools, but rather as a mindset or a catalyst for socio-political change.

The foundation of design literacy often begins with an introduction to an array of tools and canvases applied to a made up problem within the safe contexts of the university. This allows students to customise their learning by getting acquainted with the design vocabulary, methods and processes, while enabling them to discern from other modes of approaching solutions and problem solving. This increases their metacognition and ability to effectively apply design tools to their work. However, at the same time, the nature of such projects briefs give a false impression of control over the design process as they are usually open to interpretation, without much restriction.

This in turn generates the unavoidable problem of "distortion" as mentioned in discussion with one of our partners, as he voiced difficulties in his past experience of engaging design students for collaborative projects. It often occurs that students who have only had experience in these types of projects end up assuming the same amount of perceived control when "reframing the brief" for these assigned projects, in a way that it goes off tangent from the original intent, rendering the concepts futile for the collaborators.

Thus, it would appear that developing design literacy seems to benefit from blurring the boundaries between the university and the surrounding societal setting as it enables the students to see the consequences of their design actions (Dewey, 1938). Or in other words, design literacy can be practiced in a closed classroom setting, but it is experienced when the classroom blends itself with the surrounding context. Returning to the SCET framework introduced earlier in this paper, it seems that space, community, and emotions serve as triggers for transformation. This seems to be in line with Dewey's $(1930,1938)$ and hooks's $(1994)$ arguments on reconciling the mind-body separation plaguing our classrooms. Or in other words, in order for the students to move from sympathy to empathy, we, as educators, ought to understand the lived world of our students to provide them with courses that reconcile the mind-body separation.

Moreover, IDBM Challenge being the first course many students take in their graduate studies, presents us with the opportunity to instil values and design circumstances best suited to nurture these traits while they are new to the city and undergoing a transition phase in their lives. This course sets the tone for their mind-set and approach towards challenging issues and social awareness that they would carry with them throughout. 


\section{Concluding remarks}

Extant literature has illustrated positive outcomes in learning contexts when design practices are utilized as a catalyst for providing the students with opportunities to take ownership of their learning (Christensen et al., 2016; Green, 2014), thus highlighting the intertwined relationship between design and politics. That is to say, departure from designing for someone to designing with someone is a question of agency that has at least two implications: first, by becoming active participants in co-creating the learning experience enables students to shift their mindset from static to transferrable skills (Dewey, 1930; Lin, Schwartz \& Bransford, 2007) and second, experiencing this shift in a multidisciplinary team when working on a real life project provides the students with first-hand sensations on how and why one should design with, rather than for, someone (hooks, 1994).

This short paper serves as an introduction to our experimental methods, including a proposed framework for curriculum (re)design. In gist, we suggest that a critical prerequisite for students to truly grasp the notion of relational needs is for educators to set an example by employing empathy in the design of their learning environments; understanding what their concerns, ambitions and interests are, in order to design the right conditions to foster the emergence of care. To this end, the SCET framework introduced in this paper warrants more inquiry and theoretical development to push teaching and research on teaching and learning forward.

Rather than teaching empathy in the sterile manner that we currently adopt (through canvases and readings that serve as prompts) to solicit the "right" type of answers from users to generate actionable insights; we believe that emotions play an instrumental role in learning, especially in eliciting care practices.

Using our initial findings, we will be planning the 2019 edition of the course. Through which, we hope to uncover more insights that could point to a more conclusive set of results enabling us to refine the SCET framework further.

\section{References}

Ambos, T.C., Mäkelä, K., Birkinshaw, J., \& d'Este, P. (2008). When does university research get commercialized? Creating ambidexterity in research institutions. Journal of Management Studies, 45, 14241447. doi:10.1111/j.1467-6486.2008.00804.x

Anderson, L. (2006). Analytic Autoethnography. Journal of Contemporary Ethnography, 35, 373-395. doi.org/10.1177/0891241605280449

Ankrah, S., \& AL-Tabbaa, O. (2015). Universities-industry collaboration: A systematic review. Scandinavian Journal of Management, 31, 387-408. doi:10.1016/j.scaman.2015.02.003

Arum, R., \& Roksa, J. (2011). Academically adrift: Limited learning on college campuses. Chicago, IL: University of Chicago Press.

Ashworth, P. \& Lucas, U. (2000). Achieving empathy and engagement: A practical approach to the design, conduct and reporting of phenomenographic research. Studies in Higher Education, 25, 295-308. doi:10.1080/713696153

Bain, K. (2004). What the best college teachers do. Boston, MA: Harvard University Press.

Brown, B. (2013, 10 Dec 2013). Brené Brown on empathy. The RSA. Retrieved from https://www.thersa.org/discover/videos/rsa-shorts/2013/12/Brene-Brown-on-Empathy [accessed on 31 Jan 2019]

Brown, T. (2008). Change by Design. New York, NY: Harper Business.

Bruneel, J., D’Este, P., \& Salter, A. (2010). Investigating the factors that diminish the barriers to universityindustry collaboration. Research Policy, 39, 858-868. doi: 10.1016/j.respol.2010.03.006

Buchanan, R. (1992). Wicked Problems in Design Thinking. Design Issues, 8, 5-21. doi: 10.2307/1511637

Burdick, A., \& Willis, H. (2011). Digital learning, digital scholarship and design thinking. Design Studies, 32, 546556. doi:10.1016/j.destud.2011.07.005 
Christensen, K. S., Hjorth, M., Iversen, O. S., \& Blikstein, P. (2016). Towards a formal assessment of design literacy: Analyzing K-12 students' stance towards inquiry. Design Studies, 46, 125-151. doi:10.1016/j.destud.2016.05.002

Clark, B.R. (1998). Creating Entrepreneurial Universities: Organisational Pathways of Transformation. Issues in Higher Education. Oxford, England: Pergamon.

Coyne, R. (2005). Wicked problems revisited. Design Studies, 26, 5-17. doi:10.1016/j.destud.2004.06.005

Cross, A. (1980). Design and general education. Design Studies, 1, 202-206. doi:10.1016/0142-694X(80)900046

Cross, A. (1984). Towards an understanding of the intrinsic values of design education. Design Studies, 5, 3139. doi:10.1016/0142-694X(84)90026-7

Dewey, J. (1930). Democracy and education: An introduction to the philosophy of education. Norwood, MA: Norwood Press.

Dewey, J. (1938). Experience and education. New York, NY: Touchstone.

Dorst, K. (2011). The core of 'design thinking' and its application. Design Studies, 32, 521-532. doi: 10.1016/j.destud.2011.07.006

Dunne, A., \& Raby, F. (2013). Speculative Everything: Design, Fiction, and Social Dreaming. Boston, MA: The MIT Press.

Fink, L. D. (2013). Creating significant learning experiences. San Francisco, CA: Jossey-Bass.

Gioia, D. A., \& Chittipeddi, K. (1991). Sensemaking and Sensegiving in Strategic Change Initiation. Strategic Management Journal, 12, 433-448. doi:10.1002/smj.4250120604

Gioia, D. A., Corley, K. G., \& Hamilton, A. L. (2012). Seeking Qualitative Rigor in Inductive Research: Notes on the Gioia Methodology. Organizational Research Methods, 16, 15-31. doi:10.1177/1094428112452151

Glasser, H. (2018). Toward robust foundations for sustainable well-being societies: Learning to change by changing how we learn. In J. W. Cook (Ed.), Sustainability, human well-being, and the future of education (pp. 31-90). Cham, Switzerland: Palgrave.

Green, M. (2014). Transformational design literacies: children as active place-makers. Children's Geographies, 12, 189-204. doi:10.1080/14733285.2013.812305

Herrington, J., Reeves, T.C., \& Oliver, R. (2010). A guide to authentic e-learning. London, England: Routledge.

Hess, J.L., \& Fila, N.D. (2016). The manifestation of empathy within design: findings from a service-learning course. CoDesign, 12, 93-111. doi:10.1080/15710882.2015.1135243

Ho, D.K.L., Ma, J., \& Lee, Y. (2011). Empathy@ design research: a phenomenological study on young people experiencing participatory design for social inclusion. CoDesign, 7, 95-106. doi:

10.1080/15710882.2011.609893

hooks, b. (1994). Teaching to transgress. New York, NY: Routledge.

Hyun, E. (2011). Transdisciplinary higher education curriculum: a complicated cultural artifact. Research in Higher Education Journal, 11, 1-19.

Kellner, D. (2003). Toward a critical theory of education. Democracy \& Nature, 9, 51-64. doi: $10.1080 / 1085566032000074940$

Killick, D. (2012). Seeing-ourselves-in-the-world: Developing global citizenship through international mobility and campus community. Journal of Studies in International Education, 16, 372-389. doi: $10.1177 / 1028315311431893$

Kimbell, L. (2011). Rethinking Design Thinking: Part I. Design and Culture, 3, 285-306. doi: 10.2752/175470811X13071166525216

Kimbell, L. (2012). Rethinking Design Thinking: Part II. Design and Culture, 4, 129-148. doi: $10.2752 / 175470812 \times 13281948975413$ 
Kress, G., \& van Leeuwen, T. (2006). Reading Images: The Grammar of Visual Design. London, England: Routledge.

Lin, X., Schwartz, D. L., \& Bransford, J. (2007). Intercultural adaptive expertise: explicit and implicit lessons from Dr. Hatano. Human Development, 50, 65-72. doi:10.1159/000097686.

Marginson, S., \& Rhoades, G. (2002). Beyond national states, markets, and systems of higher education: A glonacal agency heuristic. Higher Education, 43, 281-309. doi:10.1023/A:1014699605875

McAllister, G., \& Irvine, J.J. (2002). The role of empathy in teaching culturally diverse students: A qualitative study of teachers' beliefs. Journal of Teacher Education, 53, 433-443. doi:10.1177/002248702237397

Meyer, D.K., \& Turner, J.C. (2006). Re-conceptualizing emotion and motivation to learn in classroom contexts. Educational Psychology Review, 18, 377-390. doi:10.1007/s10648-006-9032-1

Mezirow, J. (1991). Transformative dimensions of adult learning. San Francisco, CA: Jossey-Bass.

Müller, B. (2018). Co-creation. In T. Beyes \& J. Metelmann (Eds.), The Creativity Complex: A Companion to Contemporary Culture (pp. 63-69). Bielefeld, Germany: transcript.

Nielsen, L. M., \& Braenne, K. (2007). Design Literacy for Longer Lasting Products. Studies in Material Thinking, 9, 1-9.

Norman, D. (2013). The Design of Everyday Things. New York, NY: Basic Books.

Proserpio, L., \& Gioia, D.A. (2007). Teaching the virtual generation. Academy of Management Learning \& Education, 6, 69-80. doi:10.5465/amle.2007.24401703

Redpath, L. (2012). Confronting the bias against on-line learning in management education. Academy of Management Learning \& Education, 11, 125-140. doi:10.5465/amle.2010.0044

Rittel, H.W., \& Webber, M.M. (1973). Dilemmas in a general theory of planning. Policy Sciences, 4, 155-169. doi: $10.1007 /$ BF01405730

Rose, G. (2016). Visual methodologies. London, England: SAGE.

Rowe, P. (1987]. Design Thinking. Cambridge, MA: MIT Press.

Schenck, J., \& Cruickshank, J. (2015). Evolving Kolb: Experiential Education in the Age of Neuroscience. Journal of Experiential Education, 38, 73-95. doi: 10.1177/1053825914547153

Schön, D. A. (1983). The Reflective Practitioner: How Professionals Think in Action. New York, NY: Basic Books.

Simon, H. (1969). Sciences of the Artificial. Cambridge, MA: MIT Press.

Smeenk, W., Sturm, J., \& Eggen, B. (2018). Empathic handover: how would you feel? Handing over dementia experiences and feelings in empathic co-design. CoDesign, 14, 259-274. doi:10.1080/15710882.2017.1301960

Stegall, N. (2006). Designing for sustainability: A philosophy for ecologically intentional design. Design Issues, 22, 56-63. doi:10.1162/desi.2006.22.2.56

Taylor, E.W. (1997). Building upon the theoretical debate: A critical review of the empirical studies of Mezirow's transformative learning theory. Adult Education Quarterly, 48,34-59. doi:10.1177/074171369704800104

Teo, Y. Y. (2018). This is what inequality looks like. Singapore: Ethos Books.

Thorpe, A., \& Gamman, L. (2011). Design with society: why socially responsive design is good enough. CoDesign, 7, 217-230. doi: 10.1080/15710882.2011.630477

Yelavich, S. (2014). Introduction. In S. Yelavich, \& B. Adams (Eds.), Design as future-making (pp. 12-17). London, England: Bloomsbury. 